\title{
Phenolic profiles of nectar and honey of Quillaja saponaria Mol. (Quillajaceae) as potential chemical markers
}

\author{
Gloria Montenegro, Javiera Díaz-Forestier, Carolina Fredes and Sharon Rodríguez \\ Departamento de Ciencias Vegetales, Facultad de Agronomía e Ingeniería Forestal, Pontificia Universidad Católica de Chile, Santiago, Chile
}

\begin{abstract}
Quillaja saponaria Mol. (Quillajaceae) is one of the most important melliferous species in Chile, mainly as a source of monofloral honey. Honey made by A. mellifera presents biological activity against pathogens and antioxidant capacity associated with the presence of phenolic compounds deriving from the nectar, as a result of bee honey foraging. The aim of this study was to identify and quantify the phenolic compounds from the floral nectar of $Q$. saponaria and the honey made in apiaries in the central zone, and compare the composition of the chromatographic profiles of nectar and honey to known phenolic compounds. The results obtained by HPLC-DAD (high-performance liquid chromatography with diode-array detection) showed a similar profile of phenolic compounds, in which gallic acid, myricetin, rutin, quercetin and naringenin were identified. The phenolic compounds detected could be used as a reference for future studies for determining potential chemical markers of this honey, complementing the present identification of honeys by determining their botanical origin. The identification of bioindicators of the floral origins for honey of this species could provide added value to honey commercialization by certifying the botanical origin of their chemical features and biological attributes.
\end{abstract}

Key words: Apis mellifera; chromatographic profile; floral nectar; honey; phenolic compounds; Quillaja saponaria.

\section{INTRODUCTION}

The composition of floral nectar, especially the relative proportion of sugars and amino acids, plays an important role in plant-pollinator interaction and its evolution (Simpson and Neff, 1983; Real and Rathcke 1988). Nectar is an aqueous plant secretion whose content is mainly sugars and amino acids (Baker and Baker, 1983; Nicolson and Thornburg, 2007; Gonzalez-Teuber and Heil, 2009). Nectar is made by a large number of higher plants in order to attract insect or vertebrate pollinators which transport pollen from plant to plant, becoming a key attribute for increasing cross-pollination as a response to visiting insects (Petanidou, 2005; Pacini and Nepi, 2007). Flowers secreting more nectar show more successful pollination events (Mitchell and Waser, 1992; Nepi et al., 2001; Langenberger and Davis 2002; Mačukanović et al., 2004; Fischer and Leal, 2006; Higginson et al., 2006).

Nectar collected by bees, particularly Apis mellifera L., is converted into honey by enzymatic action and dehydration, producing about 18\% water content (Moguel et al., 2005). Honey is a sugar-saturated solution and one of the most complex natural carbohydrate mixtures. It contains glucose, fructose and other carbohydrates, which are a combination of at least 11 disaccharides, 11 trisaccharides and several oligosaccharides (Siddiqui and Furgala, 1967, 1968; Low and Sporns, 1988); it also has antioxidants, terpenoids and secondary compounds such as phenols and alkaloids, among others (Nicolson and Thornburg, 2007).

Sugars are the main component of honey (around 95\% of the dry weight), with a relative amount of fructose and glucose (60-80\%) which is useful for monofloral honey classification (Persano et al., 1995; Piccirillo et al., 1998; Persano and Piro, 2004; Bogdanov et al., 2004). In Chile, Montenegro et al. (2004) identified eight species of native plants showing an intensive use as nectar source by $A$. mellifera and only five species used as the source for monofloral honeys, which are selected by bees mainly due to the volume and chemical composition of nectar offered by the flowers. Q. saponaria Mol. (soapbark) is among these native plants; it is an endemic Quillajaceae of Central Chile with highly attractive flowers for honeybees (Ramírez and Montenegro, 2004; Díaz, 2007). Nectar foraging is high and high levels of monofloral honey production are reached (Montenegro et al., 2008). It is highly appreciated in national and international markets, due to its nematicidal and antifungal properties (San Martin and Briones, 1999; Montenegro et al., 2001; Montenegro et al., 2009) and for its known chemical features and biological attributes (Montenegro et al., 2010a, b).

The chemical analysis of nectar samples has been focused on the concentration and relative proportions of carbohydrates (Gil et al., 1995; Gardener and Gillman, 2001). Secondary metabolites, generally appearing in low levels but clearly involved in ecological interactions, have been also reported (Radhika et al., 2010). Extensive research has explained the role played by the components in the antioxidant ability of honey (Busserolles et al., 2002; Gheldof and Engeseth, 2002; Gheldof et al., 2002; Schramm et al., 2003; Muñoz et al., 2007). In addition to polyphenols, honey presents a variety of natural compounds, such as nitrogen compounds, carotenoids and vitamin $\mathrm{C}$, which are widely known for their antioxidant activity (Larson, 1988).

This study assumes that the nectar content of phenolic compounds represents an essential element which, in most cases, defines the level of antioxidant activity of a specific honey sample, although all components act altogether to produce this activity. The aims of this study were to identify 
and determine quantitatively the phenolic components of floral nectar from $Q$. saponaria and honey produced in apiaries in the central zone of Chile, determine the presence and amount of phenolic compounds in soapbark nectar, and compare the composition of the chromatographic profiles of nectar and honey to known phenolic compounds.

\section{MATERIALS AND METHODS}

\section{Floral nectar collection}

Nectar from flowers of three Q. saponaria trees was collected in Manquehue Hill in Santiago $\left(33^{\circ} 22^{\prime} \mathrm{SL}, 70^{\circ} 35^{\prime} \mathrm{WL}\right.$, Metropolitan Region). The nectar collected from several flowers of the same tree (experimental unit) was placed in Eppendorf tubes and stored at $-20^{\circ} \mathrm{C}$ before further analysis in the laboratory. Additionally, nectar from the honey crop of A. mellifera foraging on soapbark trees was also extracted. The botanical origin of the nectar was confirmed by microscopic analysis of the existing pollen (Loveaux et al., 1970; Low et al., 1988). The samples were filtered and stored at $-20{ }^{\circ} \mathrm{C}$ before their analysis.

Honey collection

The honeys were obtained from apiaries located in the Metropolitan Region and the Region of Maule, Chile, and encoded as RM-012005-M337, VII-032005-M338 and VII032003-M243, respectively. The botanical origin of the honeys was determined according to Chilean Standard 2981 (INN, 2006). $10 \mathrm{~g}$ of honey were diluted in $10 \mathrm{~mL}$ of distilled water, and then centrifuged at 2,500 rpm for 5 minutes. The supernatant was eliminated and the sedimented pollen was resuspended in $0.1 \mathrm{~mL}$ of distilled water. Five preparations from each honey sample were elaborated for optical microscopy and the pollen grains from each sample were identified using palinoteque and reference bibliography (Heusser, 1971; Hodges, 1984; Ertdmann, 1986; Montenegro, 2000).

\section{Sample preparation}

The nectar from the trees was diluted to $50 \%$ with methanol and then centrifuged. Phenolic extracts of the honey and nectar from the bee crops were obtained, following the methodology of Tomás-Barberán et al. $(1993,2001)$.

A volume of $3 \mathrm{~mL}$ of nectar was diluted with $\mathrm{pH} 2$ water to a final volume of $12 \mathrm{~mL}$ for the elaboration of the nectar extract. The solution was transferred to a small resin column Amberlita XAD-2 (90 mm height x $10 \mathrm{~mm}$ diameter). Then it was eluted with $6 \mathrm{~mL}$ of $\mathrm{pH} 2$ water, with $12 \mathrm{~mL}$ of distilled water, and finally with $18 \mathrm{~mL}$ of pure methanol. The methanolic fraction was evaporated to dryness in a stove at $45^{\circ} \mathrm{C}$. The residue was re-suspended in $1 \mathrm{~mL}$ of distilled water, and $1 \mathrm{~mL}$ of ethyl ether was added. The organic phase was extracted and the process was repeated twice. The resulting solution was concentrated to dryness in a stove at $45^{\circ} \mathrm{C}$, and the residue was re-suspended in $0.12 \mathrm{~mL}$ of HPLC-degree-methanol.

\section{Determination of phenolic compounds}

$0.02 \mathrm{~mL}$ of the extracts and nectar diluted in methanol were injected into a HPLC (HP1100) with a C-18 Agilent reversed- phase column, with diode-array detection to determine the phenolic compounds from the samples. Two solvents were used for the mobile phase: water and acetonitrile (pH3). A system of elution gradient was used (Markham et al., 1970) (Table 1).

TABLE 1

Gradient of solvents elusion mobile phase (solvent A: water; solvent $\mathrm{B}$ : acetonitrile ( $\mathrm{pH} 3)$ )

\begin{tabular}{ccc}
\hline Time $(\mathrm{min})$ & \% solvent A & \% solvent B \\
\hline 0 & 84 & 16 \\
3 & 84 & 16 \\
12 & 40 & 60 \\
14 & 40 & 60 \\
14 & 84 & 16 \\
\hline
\end{tabular}

A flow rate of $1 \mathrm{~mL}$ minute ${ }^{-1}$ was used, with 15 minute elution time. The detection was made at $280 \mathrm{~nm}$ and $314 \mathrm{~nm}$. Calibration curves with pure standards in methanol were made in order to identify the phenolic compounds existing in the nectar samples and the extracts. The standards were commercially obtained (Sigma-Aldrich).

\section{Statistical analysis}

The statistical software Infostat was used for the analyses (version 2012, Córdoba, Argentina) using analysis of variance, in order to determine the existence of significant differences among honeys analyzed for each quantified compound. The differences among honeys were determined by the Tukey test $(\mathrm{p}<0.05)$.

\section{RESULTS AND DISCUSSION}

Table 2 shows the results from the palynological analysis of the studied honeys. The three honey samples analyzed in this study were by definition monofloral from $Q$. saponaria, as they had more than $45 \%$ pollen from this species (INN, 2006), but with different relative percentages of participation. Honey RM-012005-M337 and honey VII-032003-M243 also presented important amounts of Lithrea caustica, a typical species from the shrub and sclerophyllous forest of Central Chile. Honey VII032005-M338 showed the smallest proportion of $Q$. saponaria within the pollen fraction, presenting high percentages of Mellilotus indicus and Lotus uliginosus, species introduced and ruderal in Chile.

The chromatograms recorded at different wave lengths with HPLC - DAD show that most compounds were detected at $314 \mathrm{~nm}$. The results obtained allowed identification of a series of phenolic compounds; at least 10 have been identified, with gallic acid as the principal compound. The corroboration of the presence of this compound was possible by the addition of growing concentrations of pure standard gallic acid to the samples of nectar extracts.

Fig. 1 presents nectar chromatograms collected from $Q$. saponaria flowers from the studied trees. Fig. 2 shows the chromatograms of the nectar extracts from bees foraging in 
TABLE 2

Results of the palynological analysis of the studied honeys

\begin{tabular}{|c|c|c|c|}
\hline Honey code & Origin & Presence of $Q$. saponaria $(\%)($ mean \pm SD) & $\begin{array}{l}\text { Other present species }(\%) \\
(\text { mean } \pm \text { SD) }\end{array}$ \\
\hline RM-012005-M337 & 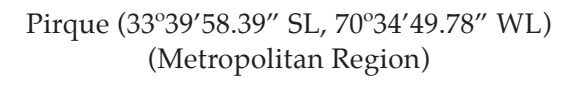 & $75.9 \% \pm 2.7$ & $\begin{array}{l}\text { Lithrea caustica } \\
\quad(9.5 \% \pm 1.9)\end{array}$ \\
\hline VII-032005-M338 & $\begin{array}{c}\text { Los Lunes }\left(35^{\circ} 31^{\prime} 58.99 \mathrm{SL}, 71^{\circ} 29^{\prime} 28.19^{\prime \prime} \mathrm{WL}\right) \\
\text { (Region of Maule) }\end{array}$ & $50.7 \% \pm 5.6$ & $\begin{array}{l}\text { Melilotus indicus } \\
(10.5 \% \pm 3.4) \\
\text { Lotus uliginosus } \\
\quad(6.5 \% \pm 2.8)\end{array}$ \\
\hline VII-032003-M243 & $\begin{array}{c}\text { Itahué }\left(35^{\circ} 08^{\prime} 19.20^{\prime \prime} \mathrm{SL}, 71^{\circ} 22^{\prime} 05.78^{\prime \prime} \mathrm{WL}\right) \\
\text { (Region of Maule) }\end{array}$ & $53.4 \% \pm 51$ & $\begin{array}{l}\text { Lithrea caustica } \\
(15.3 \% \pm 3.7) \\
\text { Luma apiculata } \\
(6.2 \% \pm 2.4) \\
\text { Rubus ulmifolius } \\
(6.2 \% \pm 2.4)\end{array}$ \\
\hline
\end{tabular}
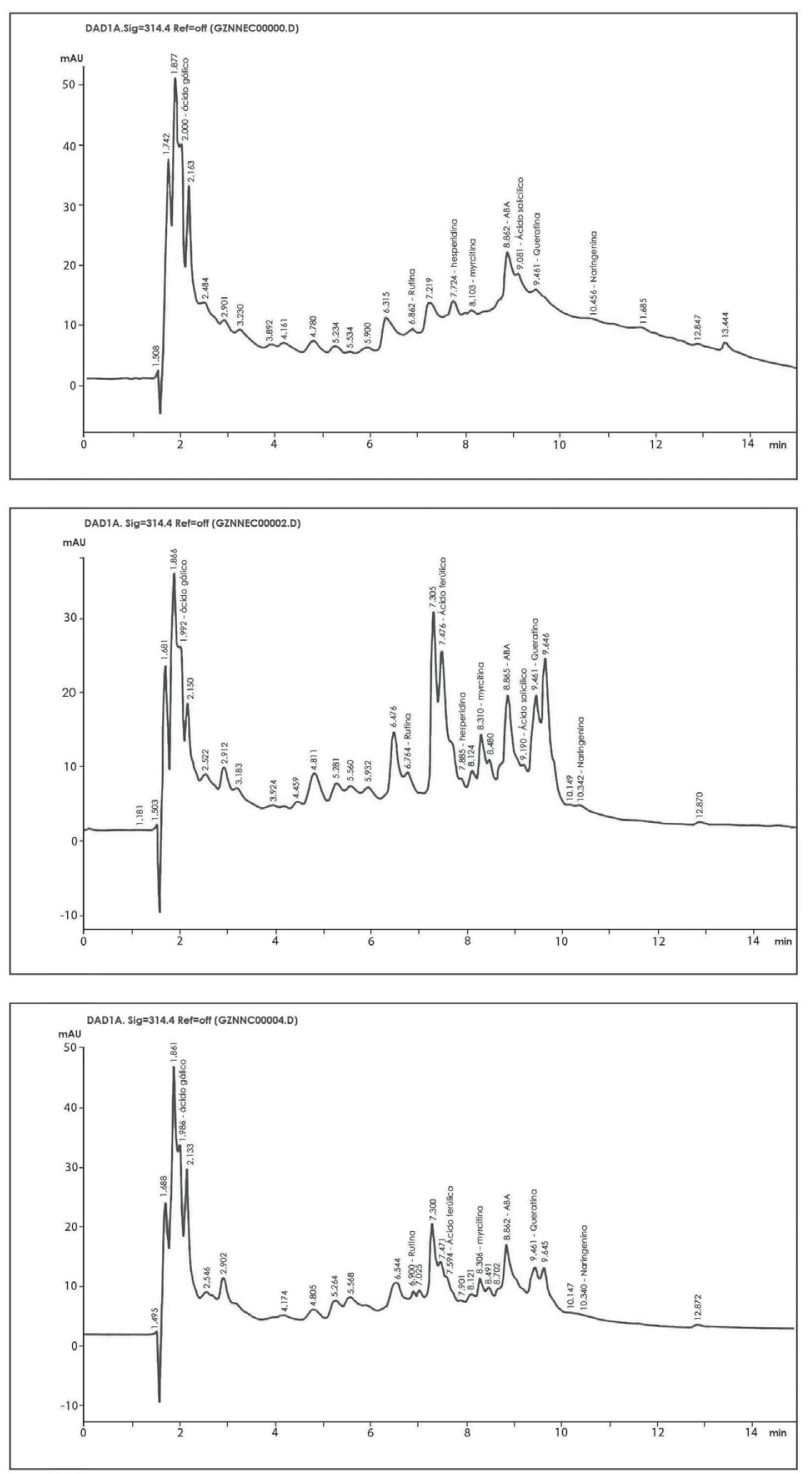

Figure 1. HPLC-DAD chromatograms of phenolic compounds identified in nectar extracts (A, B and C) of $Q$. saponaria obtained at $314 \mathrm{~nm}$.
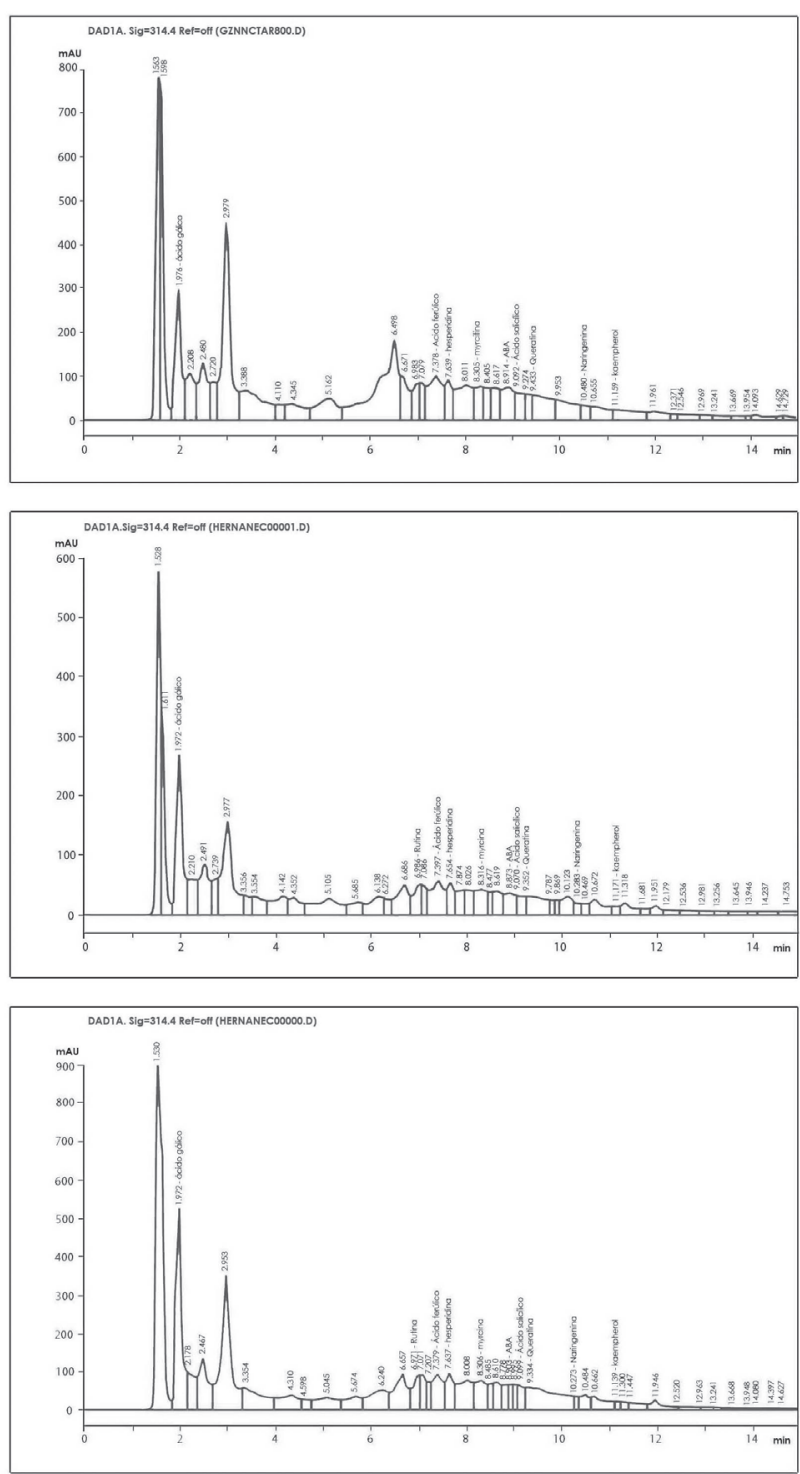

Figure 2. HPLC-DAD chromatograms of phenolic compounds identified in nectar extracts (A, B and C) of the crop of honeybees obtained at $314 \mathrm{~nm}$. 
soapbark flowers, and Fig. 3 shows the extract chromatograms from the studied honeys.

The analyses by HPLC-DAD of the nectar extracts (of $Q$. saponaria flowers and the crop of honeybees) (Fig. 1 and 2) and the honey extracts (Fig. 3), showed a similar profile of phenolic compounds, which supports the idea that the antioxidant activity of honey may be obtained from the nectar of this endemic shrub of Central Chile.

The main compound identified was gallic acid, which corresponds to a phenolic acid whose antioxidant activity equivalent in trolox is $3.01 \mathrm{mmol} \mathrm{L}^{-1}$ (Miller and Rice-Evans, 1995), with known antimutagenic activity and protective action against liver damage caused by carbon tetrachloride (Urquiaga and Leighton, 2000).

Abscisic acid (ABA) was another compound recorded in all the chromatograms, which is a plant hormone associated with the protection of plants in conditions of environmental
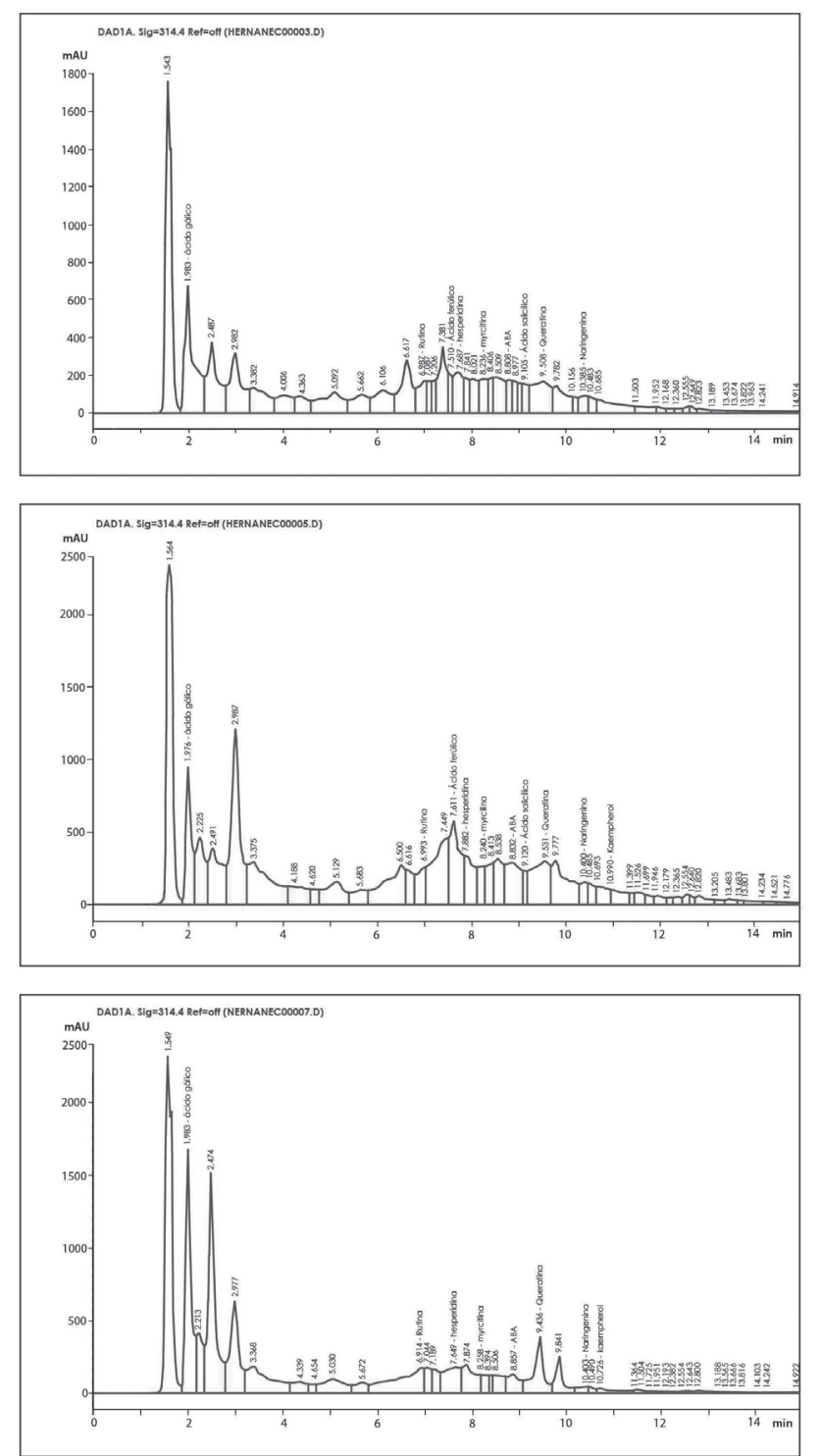

Figure 3. HPLC-DAD chromatograms of phenolic compounds identified in honey extracts (A: RM-012005-337, B: VII-032005-338 and C: VII-032003-M243) obtained at $314 \mathrm{~nm}$. stress. The presence of this hormone in nectar is well known (Goodwin and Mercer, 1983; Ferreres et al., 1996), and therefore it may be present in honey in variable amounts.

Nectar composition is influenced by the environmental conditions of the place where the plant grew (Pacini et al., 2003), which may act on the regular presence of phenolic compounds and abscisic acid, and on some honey compounds. Walters et al. (1999) observed that plants may stimulate the synthesis of secondary metabolites, diminishing damages by their ability to capture free radicals under stress conditions, and reduce the penetration of UV-B ultraviolet radiation. These stress conditions increase the ABA concentration in the nectar (Taiz and Zeiger, 1991), and therefore, in honey. The high interannual variability of the climate conditions of the central zone of Chile may be associated with the representation of these compounds in the honey produced from $Q$. saponaria.

The results indicated the presence of a predominant phenolic compound, gallic acid, and several similar compounds in the samples of nectar and honey. These compounds could act as chemical markers of floral origin for honeys of this species; however, a larger number of honey samples should be analyzed to determine a correlation among the existing compounds in the nectar and honey from $Q$. saponaria. On the other hand, the effect of other species present in honey, which vary in each production season (Montenegro, 2002; Montenegro et al., 2003, 2005, 2008, 2009, 2010a, 2010b) providing specific phenolic compounds to honey, must be considered.

The phenolic compounds identified in this study are ecologically and productively important: they play an important role in the attraction and nutrition of pollinators (Adler, 2000), they may prevent oxidation of other nectar substances (hinder the entrance of pathogens through the nectary (Cushnie and Lamb, 2005) and might provide an aggregate value to honey commercialization by the certification of the botanical origin of chemical features and biological attributes.

The study concludes that the results on the phenolic composition of the samples of $Q$. saponaria nectar and honeys are the first evidence generated on this topicfor an emblematic Chilean species . The establishment of compared chromatographic profiles for nectar and honey from native plant species important for honeybee in Chile will allow the determination of potential chemical honey markers as a supplement to the traditional melisopalynological analysis, which could provide a higher added value to honey by the presence of chemical compounds of high biological activity.

\section{ACKNOWLEDGEMENTS}

This research was financed by FONDECYT project 1110808 to G. Montenegro.

\section{REFERENCES}

ADLER LS 2000. The ecological significance of toxic nectar. Oikos 91: 409-420. BAKER HG, BAKER I (1983) Floral nectar sugar constituents in relation to pollinator type. In CE Jone, RJ Little [eds.]. Handbook of experimental pollination biology, 117 - 141. Van Nostrand Reinhold, New York, New York, USA.

BOGDANOV S, RUOFF K, PERSANO L (2004) Physico-chemical method for the characterization of unifloral honey: a review. Apidologie 35(1): S4-S17.

BUSSEROLLES J, GUEUX E, ROCK E, MAZUR A, RAYSSIGUIER Y (2002) Substituting honey for refined carbohydrate protects rats from 
hypertriglyceridemic and prooxidative effects of fructosa. J Agric Food Chem 50(21): 5870-5877.

CUSHNIE TP, LAMB AJ (2005) Antimicrobial activity of flavonoids. Int J Antimicrob Age 26: 343-356.

DÍAZ J (2007) Estructura de los nectarios de Q. saponaria, dinámica de secreción de néctar y polinizadores asociados: incidencias en la producción de miel. Tesis de Magíster en Recursos Naturales, Facultad de Agronomía e Ingeniería Forestal, Pontificia Universidad Católica de Chile.

ERDTMANN G (1986) Pollen Morphology and Plant Taxonomy; Angiosperms (an Introduction to Palynology). EJ Brill, Leiden, 553 p.

FERRERES F, ANDRADE P, TOMÁS-BARBERAN FA (1996) Natural occurrence of absicisic acid in Portuguese heather honey and floral nectar. J Agric Food Chem 44: 2053-2056.

FISCHER E, LEAL IR (2006) Effect of nectar secretion rate on pollination success of Passiflora coccinea (Passifloraceae) in the central amazon. Braz J Biol 66: 747-754.

GARDENER MC, GILLMAN MPJ (2001) Analizing variability in nectar amino acids: composition is significantly less variable than concentration. J Chem Ecol 27: 2545-2558.

GHELDOF N, ENGESETH NJ (2002) Antioxidant capacity of honey from various floral sources based on the determination of oxygen radical absorbance and inhibition of in vitro lipoprotein oxidation in human serum samples. J Agric Food Chem 50(3): 3050-3055.

GHELDOF N, WANG XH, ENGESETH NJ (2002) Identification of antioxidant components of honeys from various floral sources. J Agric Food Chem 50: 5870-5877.

GIL MI, FERRERES F, ORTIZ R, SUBRA E, TOMÁS-BARBERÁN FAJ (1995) Plant phenolic metabolites and floral origin of rosemary honey. J Agric Food Chem 43: 2833-2838.

GONZALEZ-TEUBER M, HEIL M (2009) Nectar chemistry is tailored for both attraction of mutualists and protection from exploiters. Plant Signal Behav 4: 809-813.

GOODWIN TW, MERCER EI (1983) Introduction to Plant Biochemistry. ed 2. Pergamon Press, Oxford, England.

HEUSSER C (1971) Pollen and spores of Chile. The University of Arizona Press. Tucson, Arizona. EE.UU. 167 p.

HIGGINSON AD, GILBERT FS, BARNARD CJ (2006) Morphological correlates of nectar production used by honeybees. Ecol Entomol 31: 269-276.

HODGES D (1984) The pollen loads of the honeybee, a guide to their identification by colour and form. London Inter Bee Res Assoc, $120 \mathrm{p}$.

LANGENBERGER MW, DAVIS AR (2002) Temporal changes in floral nectar production, reabsorption, and composition associated with dichogamy in annual Caraway (Carum carvi; Apiaceae). Am J Botany 89(10): 1588-1598

LARSON RA (1988) The antioxidants of higher plants. Phytochemistry 27: 969-978.

URQUiAGA I, LEIGHTON F (2000) Plant Polyphenol Antioxidants and Oxidative Stress. Biol Res 33 (2): 55-64

LOVEAUX J, MAURIZIO A, VORWOHL G (1970) Methods of melissopalynology. Bee World 51: 125-138.

LOW NH, SPORNS P (1988) Analysis and Quantitation of Minor Diand Trisaccharides in Honey, Using Capillary Gas Chromatography. J Food Sci 53(2): 558-561.

LOW NH, NELSON DL, SPORNS P (1988) Carbohydrate Analysis of Western Canadian Honeys and their Nectar Sources to Determine the Origin of Honey Olisaccharides. J Apic Res 27(4): 245-251.

MAČUKANOVIĆ M, DULETIĆ S, JOCIĆ G (2004) Nectar production in three melliferous species of Lamiaceae in natural and experimental conditions. Acta Veterinaria (Beograd) 54(5-6): 475-487.

MARKHAM K, MABRY TJ, THOMAS MB (1970) The systematic identification of flavonoid. Springer Verlag., Berlin-New York. p. 1-175.

MILLER NJ, RICE-EVANS CA (1995) Antioxidant activity of resveratrol in red wine. Clin Chem 41:1789.

MITCHELL RJ, WASER NM (1992) Adaptive significance of Ipomopsis aggregata nectar production: pollination success of single flowers. Ecology 73: 633-638.

MOGUEL Y, ECHAZARRETA C, MORA R (2005) Calidad fisicoquímica de la miel de abeja A. mellifera producida en el estado de Yucatán durante diferentes etapas del proceso de producción y tipos de floración. Técnica Pecuaria en México 43(3): 323-334.

MONTENEGRO G (2000) Chile nuestra flora útil, guía de uso apícola, medicinal folclórica, artesanal y ornamental. Ediciones Universidad Católica de Chile. Santiago, Chile. 153 p.

MONTENEGRO G, PEÑA R, TIMMERMAN BN (2001) La corteza de quillay (Quillaja saponaria Mol.), un recurso de la farmacopea internacional. Rev Acad Colomb Cienc Exact Fis Nat 25: 420-427.
MONTENEGRO G, PIZARRO R, ÁVILA G, GÓMEZ M, DÍAZ J, ORTEGA X GONZÁLEZ L (2004) Determinación de la flora melífera nativa de Chile, mediante el análisis palinológico de la miel. X Congreso Nacional de Botánica del Perú. Universidad Nacional de Trujillo, Trujillo, Perú.

MONTENEGRO G, GÓMEZ M, DÍAZ J, PIZARRO R (2008) Aplicación de la Norma Chilena Oficial de denominación de origen botánico de la miel para la caracterización de la producción apícola. Cien Inv Agr 35(2): 181-190.

MONTENEGRO G, SALAS F, PENA R, PIZARRO R (2009) Actividad antibacteriana y antifúngica de mieles monoflorales de Quillaja saponaria, especie endémica de Chile. Phyton 78: 141-146.

MONTENEGRO G (2002) Chile, nuestra flora útil. Guía de plantas de uso apícola alimentario, medicinal folclórico, artesanal y ornamental. Ed. Universidad Católica de Chile. Santiago, Chile. 267 pp.

MONTENEGRO G, PIZARRO R, ÁVILA G, CASTRO R, RÍOS C, MUÑOZ O, BAS F, GÓMEZ M (2003) Origen botánico y propiedades químicas de las mieles de la Región Mediterránea Árida de Chile. Cien Inv Agr 30(3):161-174

MONTENEGRO G, PIZARRO R, ÁVILA G, MUÑOZ O, MUJICA AM BAS F (2005) Determination of the botanical origin and some chemical properties of honeys from the central zone of Chile. Phyton Sp Iss: 213-223.

MONTENEGRO G, GÓMEZ M, DÍAZ-FORESTIER J, PIZARRO R (2008) Aplicación de la Norma Chilena Oficial de denominación de origen botánico de la miel para la caracterización de la producción apícola. Cien Inv Agr 35(2): 181-190.

MONTENEGRO G, SALAS F, PEÑA RC, PIZARRO R (2009) Actividad antibacteriana y antifúngica de mieles monoflorales de Quillaja saponaria, especie endémica de Chile. Phyton 78: 141-146.

MONTENEGRO G, RODRÍGUEZ S, VÍO S, GÓMEZ M, PIZARRO P, MUJICA AM, ORTEGA X (2010a) Investigación científica y tecnológica en productos apícolas. Fundación COPEC-Universidad Católica. Santiago, Chile. 240 p.

MONTENEGRO G, PEÑA RC, PIZARRO R (2010b) Multivariate analysis of pollen frequency of the native species Escallonia pulverulenta (Saxifragaceae) in Chilean honeys. Rev Bras Bot 33(4): 615-630.

MUÑOZ O, COPAJA S, SPEISKY H, PEÑA R, MONTENEGRO G (2007) Contenido de flavonoides y compuestos fenólicos de mieles chilenas e índice antioxidante. Quimica Nova 390: 848-851.

NEPI M, GUARNIERI M, PACINI E (2001) Nectar secretion, reabsorption, and sugar composition in male and female flowers of Cucurbita pepo. Intl J Plant Sci 162: 353-358.

NICOLSON SW, THORNBURG RW (2007) Nectar chemistry. In SW Nicolson, Nepi and Pacini (eds.) Nectaries and nectar. Springer, Dordrecht, Netherlands.

INN-INSTITUTO NACIONAL DE NORMALIZACIÓN (2006) NCh 2981 Of2005: Miel de abejas-Denominación de origen botánico mediante ensayo melisopalinológico. Declarada Norma Chilena Oficial de la República el 14 de diciembre de 2005 por Decreto Exento No 765 del Ministerio de Agricultura, publicada en el Diario Oficial No 38.358 el 9 de enero de 2006.

PACINI E, NEPI M, VESPRINI JL (2003) Nectar biodiversity: a short review. Plant Syst Evol 238: 7-21.

PACINI E, NEPI M (2007) Nectar production and presentation. In SW Nicolson, Nepi and Pacini (eds.) Nectaries and nectar. Springer, Dordrecht, Netherlands.

PERSANO L, PIAZZA M, SABATINI A, ACCORTI M (1995) Characterization of unifloral honey. Apidologie 26(6): 453-465.

PERSANO L, PIRO R (2004) Main European Unifloral Honey: descriptive sheets. Apidologie 35(1): 38-81.

PETANIDOU T (2005) Sugars in Mediterranean floral nectars: An ecological and evolutionary approach. J Chem Ecol 31: 106-1088.

PICCIRILLO G, RODRÍGUEZ B, OJEDA G (1998) Estudio de algunos parámetros fisicoquímicos en mieles cosechadas durante la época seca de ocho zonas apícolas del Estado Zulia, Venezuela. Revista de la Facultad de Agronomía Universidad de Zulia (Venezuela) 15: 486-497.

RADHIKA V, KOST C, BOLAND W, HEIL M (2010) The Role of Jasmonates in Floral Nectar Secretion. PLoS ONE 5(2): e9265.

RAMÍREZ R AND G MONTENEGRO (2004) Certificación del origen botánico de miel y polen corbicular pertenecientes a la comuna de Litueche, VI Región de Chile. Cien Inv Agr 31(3): 197-211.

REAL L, RATHCKE BJ (1988) Patterns of individual variability in floral resources. Ecology 69(3): 728-735.

SAN MARTÍN R, BRIONES R (1999) Industrial uses and sustainable supply of Quillaja saponaria saponins. Econ Botany 53: 302- 311. 
SCHRAMM DD, KARIM M, SCHRADER HR, HOLT RR, CARDETTI M, KEEN CL (2003) Honey with high levels of antioxidants can provide protection to healthy human subjects. J Agric Food Chem 51(5): 1500-1505.

SIDDIQUI IR, FURGALA B (1967) Isolation and Characterization of Oligosaccharides from Honey. Part I. Disaccharides. J Apic Res 6(3): 139-145.

SIDDIQUI IR, FURGALA B (1968) Isolation and Characterization of Oligosaccharides from Honey. Part II. Trisaccharides. J Apic Res 7(1): 51-59.

SIMPSON BB, NEFF JL (1983) Evolution and diversity of floral rewards. In Handbook of experimental pollination biology. JONES CE, LITTLE RJ (eds.). New York: Van Nostrand Reinhold Co. p. 142-159.
TAIZ L, ZEIGER E (1991) Plant Physiology. The Bejamin/Cummings Publishing Company, Inc., Redwood City. 565 p.

TOMÁS-BARBERÁN FA, FERRERES F, BLÁZQUEZ MA, GARCÍAVIGUERA C, TOM-LORENTE F (1993) High-performance liquid chromatography of honey Flavonoids. J Chromat 634: 41-46.

WALTERS R, ROGERS J, SHEPARD F, HORTON F. 1999. Acclimation of ArabidopsisThaliana to the light environment: the role of photoreceptors. Planta 209: 517-527. 